\title{
The Long-Run Effects of Attending an Elite School: Evidence from the UK*
}

\author{
Damon Clark \\ UC Irvine, NBER and IZA \\ Emilia Del Bono \\ University of Essex, University of Bergen and IZA
}

8th April 2015

\begin{abstract}
This paper estimates the impact of elite school attendance on longrun outcomes including completed education, income and fertility. Our data consists of individuals born in the 1950s and educated in a UK district that assigned students to either elite or non-elite secondary schools. Using instrumental variables methods that exploit the school assignment formula, we find that elite school attendance had large impacts on completed education. Surprisingly, there are no significant effects on most labor market outcomes except for an increase in female income. By contrast, we document a large and significant negative impact on female fertility.
\end{abstract}

JEL Classification: I2, J24, C31, C36

Keywords: Education, school quality, instrumental variables

\footnotetext{
${ }^{*}$ We would like to thank Heather Clark and David Leon for generous help with the Aberdeen data. We also thank the staff at the Aberdeen City Library for their help with Education Committee minutes from the 1960s. We received many useful comments from Josh Angrist, Sonia Bhalotra, Kenneth Chay, Adeline Delavande, Yingying Dong, Steve Pudney and Luke Sibietta, as well as seminar participants at Cornell University, DIW Berlin, University of Essex, McGill University, SUNY Binghamton, MIT, Princeton University, the University of St. Andrews. This work contains statistical data from ONS which is crown copyright and reproduced with the permission of the controller HMSO and Queen's Printer for Scotland. The use of the ONS statistical data in this work does not imply the endorsement of the ONS in relation to the interpretation or analysis of the statistical data. We would like to thank Annarosa Pesole for her help in analyzing ONS data and Seok Min Moon for superb research assistance. Damon Clark acknowledges financial support through a National Educational Association/Spencer Foundation Post-Doctoral Research Fellowship. Emilia Del Bono acknowledges the support provided by the ESRC Centre on Micro-Social Change at ISER (grant RES-518-28-001).
} 


\section{Introduction}

In many parts of the world, including several European countries and some US cities, students are tracked into different types of high school: students perceived as academically able into elite schools, students perceived as less academically able into non-elite schools. An emerging body of evidence suggests that being tracked into the elite schools in these systems has, at best, small effects on test scores and college outcomes (Angrist et al., 2011; Clark, 2010; Dobbie and Fryer, 2011; Pop-Eleches and Urquiola, 2013). ${ }^{1}$ This is surprising. As several of these studies document, parents have strong preferences for elite schools within these systems. Indeed, much of the pressure to reform these systems stems from the perception that they represent a lottery in life chances, one in which the lucky winners assigned to the elite schools are given the prize of a better education and better later-life outcomes. ${ }^{2}$

One explanation for this combination of strong preferences and weak impacts is the possibility that parents do not understand the education production function: for example, they might overestimate the importance of peer effects. Another explanation is that parents are focused on other youth outcomes such as crime, which Deming (2010) shows can be improved when parents gain access to their preferred schools. A third explanation is that parents are focused on longer-run outcomes, and that elite school attendance improves these outcomes despite apparently modest effects on test scores and college enrollment. Unfortunately, there are few analyses of the long-run effects of elite school assignment, presumably a reflection of the difficulties associated with identifying exogenous variation in school assignments and then matching these to adult outcome data. ${ }^{3}$ This is unfortunate because other education evalu-

\footnotetext{
${ }^{1}$ In a closely related study, Cullen et al. (2006) also find small test score effects of attending "better" schools in Chicago, in this case regular public schools that are highachieving and popular with parents. An exception to this pattern of small effects is Jackson (2010), who finds larger effects of attending elite schools in Trinidad and Tobago.

${ }^{2}$ To analyze convincingly whether a selective or non-selective system is most effective we would require quasi-random assignment of students to different types of systems (such as that implemented by Duflo et al., 2011). We do not have access to this type of assignment hence make no claims as to which system is most effective.

${ }^{3}$ Dustmann et al. (2012) offer one such analysis, focusing on the impact of attending an
} 
ations have revealed a disconnect between test scores and long-run impacts (e.g., Garces et al., 2002; Krueger and Whitmore, 2001).

This paper begins to fill this gap by providing what we believe are the first estimates of the long-run impact of attending an elite school. These estimates make use of a large sample of students educated in a UK district that operated a selective high school system. Because assignment in this district was based on a strict formula, and because this formula was a highly non-linear function of assignment scores, we can exploit our knowledge of this formula to generate credible estimates of the causal effects of attending an elite school within this system. This strategy can be thought of as a heavily parameterized regression kink design (Card et al., 2012). The individuals in our sample attended school in the 1960s, and were followed and surveyed in 2001 (when they were in their late 40s). We can therefore estimate impacts on a range of long-run outcomes, including completed education, income, marriage, and fertility.

Our analysis produces three main findings. First, we find large impacts of elite school attendance on educational attainment. For women, we estimate that elite school attendance increased full-time education by 0.8 years and increased the probability of earning A-levels by 23 percentage points. Relative to average attainment among women with borderline scores that attended nonelite schools (which we refer to as the "control group" mean), this represents a 35 percent increase in completed years of post-compulsory education and a 56 percent increase in the likelihood of achieving A-level qualifications. For men, we estimate that elite school attendance increased completed years of

elite middle school in Germany. They instrument elite school attendance using date of birth relative to the school starting age, the idea being that older students will be more likely to be deemed suitable for the elite schools. The authors find that higher-track attendance in middle school has negligible effects on the type of secondary education received and on longrun outcomes such as wages and unemployment. An important caveat that could account for these findings is that, after being assigned, German students can move between tracks. There is much less scope for between-school mobility in the setting we consider. A related strand of literature considers the effect of changing the fraction of students assigned to the elite track. Duflo et al. (2011) use experimental variation to analyze tracking in Kenya; Guyon et al. (2012) argue convincingly that a Northern Ireland policy that resulted in an expansion of the elite track provides quasi-experimental variation in the size of the elite track. The relationship between average outcomes and the fraction of students tracked is an interesting and important one, but not one that we can address in this paper. 
full-time education by about one year (almost 50 percent of the control group mean) and more than doubled the probability of degree receipt. These effects likely reflect the higher barriers (i.e., non-monetary costs) to further full-time education faced by students that attended non-elite schools. For example, as shown by Clark (2010), non-elite school students may have taken too narrow a range of courses to succeed in certain degree programs. We suspect these effects are larger than those found in the previous literature because these barriers are higher in our setting than in other contexts (e.g., in the contemporary US context analyzed by Dobbie and Fryer, (2011) in which the SAT plays an important role in college admission and high school course-taking may be more similar across elite and non-elite schools).

Second, elite school attendance is at beast weakly related to income, employment and wages in the long-run. Effects for women are large and positive, although imprecisely estimated and only marginally significant. Effects for men are negative, although these are also imprecisely estimated and positive impacts on the order of conventional estimates of the return to a year of fulltime education (i.e., 5-10 percent) cannot be ruled out. We speculate that we do not find strong positive effects on labor market outcomes because elite school attendance caused (especially) men to pursue further academic education at the expense of vocational training, such that the overall impact on human capital was ambiguous. We formalize this explanation using a school quality model similar to Card and Krueger (1996) but extended to include vocational training. We then show that several implications of this explanation are confirmed in the data. We also show that the data reject the implications of several alternative hypotheses.

Third, we estimate significant impacts on fertility for women. Specifically, we find that elite school attendance led to a decrease in the number of children per woman of about 0.4 , or almost 20 percent of the mean. To the extent that this effect can be attributed solely to the additional education received by women that attended elite school, these results are very interesting. That is because we have little credible evidence regarding the causal effects of education on women's fertility outcomes, especially for women born in the 1950s 
and after. ${ }^{4}$ As Goldin (2006) and Goldin et al. (2006) have argued, changing social norms and contraceptive technology (i.e. the introduction of oral contraception) meant that these women made labor market, marriage and fertility choices in a different environment compared to that faced by their mothers and grandmothers. It follows that the effects of education on the outcomes of this generation of women may differ from the effects of education on the outcomes of earlier generations of women.

We draw three conclusions from our analysis. First, elite school attendance can have important long-run effects, including but not limited to effects on labor market outcomes. Among other things, this suggests that selective school systems can generate a type of lottery in life chances, with important advantages accruing to students that perform well on the assignment tests. To the best of our knowledge, this is the first study to provide evidence in support of this point, one stressed by opponents of this system in the 1950s and 1960s. ${ }^{5}$ This may also explain why parents exhibit strong preferences for elite-type schooling despite evidence that short-run effects can be small. Second, our findings suggest that the long-run impacts of school quality cannot be understood without reference to the wider education and labor market institutions facing students. For example, the large education impacts that we estimate likely reflect the barriers to further education faced by non-elite school students in this era. These barriers may be lower in other settings. Similarly, the small labor market impacts that we estimate for men may be driven by the vocational training options enjoyed by non-elite school students in the 1960ss.

\footnotetext{
${ }^{4}$ Geruso and Royer (2014) find no effects of the second UK compulsory schooling reform on completed fertility, a finding in line with Black et al. (2008) and Monstad et al. (2008) who study compulsory schooling reforms in Norway and the US. Currie and Morretti (2003) examine fertility responses to a different education margin, college in the US, but their focus is on infant health and they have only a crude measure of fertility, i.e. parity of a birth conditional on being observed to give birth at least once. They estimate that the effect of one additional year of maternal education reduces parity by about 0.09 chidren per woman or 4 percent of the mean.

${ }^{5}$ The argument was that it was unfair and undesirable that life chances could hinge on the answers to a few questions on tests that children took at age eleven to enter these schools. These tests were thought to be decisive in part because there was limited scope for between-school transfers after age eleven (see the discussion in Galindo-Rueda and Vignoles, 2004).
} 
Men that attended non-elite schools in other settings may have enjoyed fewer such options. Third, from a policy perspective, it follows that policy-makers would be advised to keep in mind the importance of related institutions when proposing changes to school resources and organization. For example, in the contemporary US context, it seems plausible to suppose that elite school effects would be shaped by whether non-elite school students had ready access to Advanced Placement courses (Klopfenstein, 2004) and SAT-taking opportunities (Bulman, 2013; Goodman, 2012).

\section{Institutions and data}

\subsection{The educational system in Aberdeen in the 1960s}

Our data consists of a cohort of children born in the 1950s and educated in Aberdeen, Scotland. In the 1960s, the school system in Scotland was similar to that in the rest of the UK. Education was compulsory for all children aged 5 to 15. After 7 years of primary school, at about age 12, children were transferred to one of two types of secondary school: elite schools (known as "Senior Secondary Schools" in Scotland and "Grammar Schools" in England and Wales) and non-elite schools (known as "Junior Secondary Schools" in Scotland and "Secondary Modern Schools" in England and Wales). ${ }^{6}$ In Aberdeen in the 1960s, there were three elite schools and 15 non-elite schools, three of which

\footnotetext{
${ }^{6}$ In the UK, elite high schools were established by the 1944 Education Act. Before the Act, these schools formed a class of private schools that offered scholarships in exchange for financial support from the local school district; after the Act, they received all of their funding from the district, were not allowed to charge fees and were required to admit students on the basis of academic potential assessed at the end of primary school. At its simplest, this involved all students in a district taking a test (the "11-plus"), with the elite school places going to the top-scoring students. The non-elite schools remained broadly unchanged after the Act, the important caveat being that while they previously educated all but those students that won scholarships to the elite schools, they now educated all students that failed the "11-plus".
} 
were private. ${ }^{7,8}$

\section{Secondary School Assignment}

Secondary school assignment was determined by tests and assessments that took place during the last year of primary school. The tests comprised two intelligence tests (Verbal Reasoning Quotient (VRQ) tests), an English attainment test and an arithmetic attainment test, each standardized to have mean 100 and standard deviation 15. Two assessments (of ability in English and arithmetic) were provided by the student's primary school teacher. These were averaged and standardized to give a single teacher assessment with mean 100 and standard deviation 15. This was then added to the four test scores to give an overall assignment score with mean 500. The other assessment (of the student's suitability for an elite school) was provided by the primary school head teacher (categories were "suitable", "doubtful" or "unsuitable").

The assignment procedure was as follows:

- Students with assignment scores below 540 were assigned to a non-elite school.

- Students with assignment scores of 580 or more were assigned to an elite school unless assessed by their Head as "unsuitable" or "doubtful".

- Students with scores between 560 and 579 were assigned to an elite school provided one of their intelligence scores was at least 112 and they were assessed by their Head as "suitable".

- Students with assignment score between 540 and 559 (and any remaining students from the 560-579 group) were allocated to the remaining elite school places by the Appeals Subcommittee, which used their test scores as well as additional reports written by the school Head.

\footnotetext{
${ }^{7}$ In addition to these, there were two special needs secondary schools and a convent.

${ }^{8}$ Appendix B Tables 1 and 2 use LFS data to show that the distribution of years of schooling and qualification attainment in our sample is broadly similar to that of comparison groups of individuals from the whole of the UK or the whole of Scotland.
} 
At the end of this process, the allocation was publicly announced and parents could appeal. As a result of this procedure, we expect that (i) no students with assignment scores less than 540 would be assigned to an elite school; (ii) most students with assignment scores of 560 or above would be assigned to an elite school; (iii) the fraction of students with assignment scores in the range 540-559 assigned to an elite school would be increasing in the assignment score (because a higher score likely meant a higher ranking among the borderline students considered by the Appeals Subcommittee). Our data, discussed in more detail below, are broadly consistent with this hypothesis. First, the distribution of assignment scores is as expected, with mean close to 500 (see Figure 1). Second, as seen in Figure 2, the relationship between school assignment and assignment scores has the expected pattern. ${ }^{9}$ The circles in this graph show the fraction of students attending an elite school for a 10-point interval of the score; the solid line is the probability of attending an elite school as predicted by a regression of elite school attendance on a third-order polynomial in the score and variables expected to predict elite school assignment, namely a dummy variables for scores in the borderline area (540-559), a dummy variable for scores to the right of the borderline area (560-), and interactions of these dummies and the score. The graph reveals that assignment probabilities are low for assignment scores less than 540, high for assignment scores greater than 560 and increasing in scores for assignment scores in between. ${ }^{10}$ The few students with scores below 540 that report attending an elite school may have won an appeal against an initial non-selective assignment. ${ }^{11}$ The few students

\footnotetext{
${ }^{9}$ What we term "elite school assignment" is actually "elite school attended" as reported by respondents. While the two could differ if respondents misreport the school actually attended, data from one of the four cohorts of students in our analysis (those observed in grade 7 in December 1962) suggests that any such differences are likely very small. In particular, the number that attended a non-elite school in 1964 but report attending an elite school at the time of the postal survey is 7 , while the number observed in an elite school in 1964 but who report having attended a non-elite school in 2001 is 3 (out of a total of 1,097 grade 7 survey respondents in 2001).

${ }^{10}$ Appendix A Figure 2 shows similar figures for students in different grades. These demonstrate that the rule was consistently applied for all four grades considered in our analysis.

${ }^{11}$ Grounds for appeal would likely have included the child being unwell on a test day or missing time at school through illness or family circumstances.
} 
with scores above 560 that did not attend an elite school are likely those that primary Heads deemed "unsuitable" or "doubtful".

\section{Curriculum and Exams}

At this time, the minimum school leaving age was 15; hence all students could leave after three years in whichever secondary school they were assigned to. Students could stay in the elite schools for up to six years. In the third and fourth year, they could take courses leading to the Scottish Certificate of Education (SCE) "O grade" exams. In the fifth and sixth year, they could take courses leading to SCE "H grade" exams. In the sixth year, they could also take courses leading to a "Certificate of Sixth Year Studies". This was overseen by a different examinations board and was broadly equivalent to English "A-levels".

All of the non-elite schools allowed students to stay for four years and take courses leading to "O grade" exams. They also offered more vocational-type courses. To take more courses (e.g., leading to "H grade" exams), students had to transfer to an elite school. Elite school registers suggest that few students did this. ${ }^{12}$

\section{Post-secondary options}

As described by Findlay (1973), students could pursue degree courses at universities or teacher training courses at universities or teacher training colleges. They could also pursue what Findlay describes as two main types of further education: technical and commercial. Technical education included higher-level type education leading to a Higher National Diploma (HND). This could be pursued at some universities and various "central institutions" (e.g., Colleges of Commerce, Agricultural Colleges, Nautical Colleges, Technical Colleges, Colleges and Schools of Art). In addition, it included lower-level

\footnotetext{
${ }^{12}$ For two of the three elite schools in Aberdeen, we gained access to school registers from the 1960s. These show that a small number of students entered the school for the first time at an age consistent with them having already spent four years in a non-elite school. We cannot match these students to our data, and our data do not contain information on whether a student transferred schools, but we view this as evidence that transfer opportunities were limited in our setting. We view such transfers as a mechanism that could decrease the cost of an initial non-elite school assignment.
} 
education leading to lower-level qualifications (e.g., OND, HNC, ONC and City and Guilds qualifications). This could be pursued at colleges of further education serving the local area and would typically involve day release, block release, apprenticeship, sandwich or similar course arrangements. Commercial education was typically confined to further education colleges and included secretarial and business studies courses.

The apprenticeship system provided students with another alternative to the academic track. During the 1960s the system was based on a formal or informal agreement between a firm and an apprentice. This specified the length of the apprenticeship (between three and six years) and the classroombased training component, typically day release to a technical college. The classroom-based component ensured that apprentices could acquire formal qualifications, such as City and Guilds or Business and Technology Education Council (BTEC) certificates (Steedman et al., 1998).

\subsection{The Aberdeen Children of the 1950s}

Our data come from the "Aberdeen Children of the 1950s" study. The study cohort consists of 12,150 children born in Aberdeen between 1950 and 1956 who participated in the Aberdeen Child Development Survey (Batty et al., 2004; Illsley and Wilson, 1981). ${ }^{13}$ The target population consisted of all students in primary school grades 3-7 in December 1962 (i.e., roughly aged 6-13). According to Illsley (2002), all students were covered by the study except for those attending three small private primary schools that did not take part (2.2 percent of targeted children).

In phase I of the study students were given a series of reading tests and asked to provide demographic information for themselves and their parents

\footnotetext{
${ }^{13}$ Aberdeen is a coastal town in the North-East of Scotland. In the 1960s it was the third largest city in Scotland, its economy consisting of rapidly declining traditional industries, such as fishing and shipbuilding. Its fortunes changed dramatically with the discovery of the North Sea oil in 1971. The new oil industry offered more and well-paid high skilled jobs, and generated spillover effects on other sectors, including the state and service sector (Batty et al., 2004).
} 
(address and date of birth). This information was used to link them to administrative records from the Aberdeen Maternity and Neonatal Databank (match rate 86 percent). These records included perinatal and social information collected throughout the course of their mother's pregnancy and their own birth. In phase II of the study (a year later, in July 1963) the students' medical records were extracted. In phase III of the study (March 1964) sociometric and behavioral data were collected from teachers, children and a 20 percent sample of parents. As a result of these data collection efforts, we know the father's occupation at the time of the child's birth, the premarital occupation of the child's mother, the father's occupation in 1962 (as described by the survey child) and the socio-economic status of the area in which the family lived at the time of the 1962 survey (based on dwelling age, ownership, building type and availability of domestic facilities).

District-held test score data were subsequently added to the dataset. These include all of the transfer tests and assessments discussed above (two IQ, one arithmetic, one English, one combined teacher estimate) and the scores of tests taken at ages 7 and 9. ${ }^{14}$ The test at age 7 was called the "Moray House Picture Intelligence Test" and was used to screen students for a mental handicap; the test at age 9 was the "Schonell and Adams Essential Intelligence Test" used to screen for poor readers.

In 1998 a study team began to gather new information from the original participants using administrative records on pregnancies, hospital admissions and mortality, as well as administering a postal survey. Over 97 percent of the core population $(\mathrm{N}=11,727)$ were traced. Of these, 4 percent had died, 2.5 percent had emigrated and 0.6 percent were in the armed forces (Batty et al., 2004). The postal survey was conducted in 2001. Traced participants were sent a sex-specific questionnaire that obtained a response rate of 63.7 percent.

To construct the samples used in this paper, we start with the students matched to the Aberdeen Maternity Databank $(\mathrm{N}=12,150)$ then restrict the

\footnotetext{
${ }^{14}$ This data is missing for the youngest students in the dataset, i.e. those attending grade 3 in December 1962. That is because the procedure used to assign these students had changed, and was based only on the two IQ tests.
} 
sample in several ways (see Appendix A Table 1). First, we exclude individuals who moved outside Aberdeen during the period 1962-1964, as we do not have complete information on their test results and because the vast majority of them attended secondary schools outside Aberdeen. Second, we exclude some individuals on the basis of the primary school attended. In particular, we exclude: (i) individuals who attended either a private and/or faith primary school, as some of these did not take the assignment tests and others were much less likely to attend elite schools conditional on the assignment test score; (ii) individuals who attended elite secondary school during their primary school years, as these are observed to attend an elite secondary school irrespective of their assignment test scores; (iii) individuals who attended special needs schools; and (iv) individuals who attended primary schools outside Aberdeen.

Third, since we require information on school grade at the time of the first interview we exclude individuals for whom this is not available. ${ }^{15}$ We also exclude individuals with missing assignment scores and missing age-7 and age9 test scores, all of which are used in our analysis. Fourth, since the assignment procedure changed in 1966/67, we exclude the one cohort that was subject to this new procedure. Fifth, we exclude the roughly 40 percent of individuals who did not respond to the postal survey. The latter provides information on the type of secondary school attended and most of our outcome variables.

Since we lose a large fraction of the sample to survey non-response, an obvious concern is that students assigned to elite schools were more or less likely to respond to the postal survey, and that this biases our estimates. To assess this possibility, Appendix A Figure 1 graphs the relationship between assignment score and survey response. The graph reveals a positive relationship between assignment scores and survey response rates, but no evidence of a jump or a change in the slope within the borderline score range. For a more formal as-

\footnotetext{
${ }^{15}$ Grade information was recorded on "Form A" (the one filled out by the children at the time of the first interview), but it was not added to the dataset until 1964, when it was collected as part of the sociometric data. Therefore, children with no sociometric data have no information on grades. Grade is recorded as a separate variable, and it is not based on date of birth, although the data suggest that there was not a lot of grade retention/promotion.
} 
sessment, we regressed survey response on a smooth (third-order polynomial) function of the assignment score and the set of score variables predictive of elite school assignment: dummy variables for borderline scores (540-559) and higher-than-borderline scores (560-) and interactions of these dummies and the score. We cannot reject that this second set of variables have no influence on the probability of survey response. ${ }^{16}$ As a further test, we checked that for students in grade 7 in 1962 (for whom we know secondary school assignment in March 1964 whether or not they responded to the postal survey), there is no impact of elite school attendance on the probability that individuals reply to the survey.

Table 1 presents descriptive statistics for the "base sample" that includes survey non-respondents and those in grade 3 in 1962, and the "final sample" that excludes them. As seen in the second column of this table, only a small fraction of the sample attended private secondary schools. Appendix A Figure 1 shows that there is a generally positive relationship between assignment scores and private school attendance, but a negative relationship among students with borderline scores. This suggests that while some individuals would have attended private school irrespective of the elite school outcome, others might have attended a private school as a result of failing to gain entry to an elite school. This is especially true for boys. ${ }^{17}$

There are two possible approaches to dealing with respondents that attended private schools. First, we could define the treatment of interest to be "elite public or private", under the assumption that private schools and elite state schools were similar (i.e., enrolled high-achieving students, were staffed by well qualified teachers and taught an advanced curriculum). The counterfactual would then be attending a non-elite state school. Second, we could define the treatment of interest to be attending an elite state school, such that the counterfactual combines the effects of attending private and non-elite state schools. The two approaches generate very similar results, as we might expect

\footnotetext{
${ }^{16}$ The F-statistic (associated p-value) is 0.61 (0.66) for men and 1.03 (0.39) for women.

${ }^{17}$ Only 0.4 percent of girls in our sample attended a private high school. For boys this percentage was 7.6 , comparable to the national figure at the time.
} 
given that private school students comprise a small share of the sample. ${ }^{18} \mathrm{We}$ adopt the first approach since we think it is reasonable to suppose that private schools and elite state schools were similar. In addition, as explained below, our research design is better suited to the treatment when defined as "elite or private". ${ }^{19}$ In what follows, we will use "elite school" as shorthand for "elite state school or private school".

The two far right panels of Table 1 report separate descriptive statistics for individuals that attended elite and non-elite schools. As expected, these reveal clear differences in ability and socio-economic characteristics. The difference in average ability (more than two standard deviations as measured by the total assignment score) is particularly striking.

\section{Empirical Strategy}

Our empirical strategy exploits the highly non-linear relationship between elite school attendance and assignment score seen in Figure 2. Identification comes from controlling for smooth functions of the assignment score and attributing any remaining nonlinearities to the causal effect of elite school attendance. ${ }^{20}$

More formally, supposing that elite school effects are constant and that the underlying outcome-score relationship can be represented by a third-order polynomial in the score, we can write the following model for the outcome:

$$
Y_{i}=\beta_{0}+\tau D_{i}+\beta_{1} A_{i}+\beta_{2} A_{i}^{2}+\beta_{3} A_{i}^{3}+u_{i}
$$

\footnotetext{
${ }^{18}$ Estimates based on the second approach are available upon request.

${ }^{19}$ In a previous version of the paper (Clark and Del Bono, 2014), we estimate elite school impacts in a sample that excludes respondents that attended private school. The results are very similar to those reported here and this is not surprising since the proportion of children attending a private school is very small. However, we prefer to report here estimates based on the full sample where the trated group is defined by student attending an elite state school or a private school since our instrument could in principle also determine whether or not individuals attended a private school. We thank an anonymous referee for making this important point.

${ }^{20}$ Jacob and Lefgren (2004) also use IV methods to estimate the effects of summer school programs in a similar setting (i.e., given an assignment rule that generates a treatment probability that changes sharply through a small range of assignment scores).
} 
where $u_{i}$ is a disturbance term. Even after conditioning on a flexible function of the assignment score, elite school attendance is likely to be correlated with omitted determinants of $Y$. It follows that least-squares estimates of this equation will lead to inconsistent estimates of $\tau$, the effect of interest.

To identify the causal effect of attending an elite school, we need variation in $D$ which is uncorrelated with the error term in (1). Figure 2 suggests that as the probability of elite school assignment changes sharply at specific cut-offs, four variables should be good predictors of elite school attendance: dummy variables for borderline scores (540-559) and higher-than-borderline scores (560-) and the interactions of these dummies and the score. With this in mind, we estimate two-stage least squares (2SLS) models in which these are the excluded instruments. In other words, our first stage equation is as follows:

$$
\begin{gathered}
D_{i}=\gamma_{0}+\gamma_{1} I\left[540 \leq A_{i}<560\right]+\gamma_{2} I\left[A_{i} \geq 560\right]+\gamma_{3} I\left[540 \leq A_{i}<560\right] * A_{i}+ \\
+\gamma_{4} I\left[A_{i} \geq 560\right] * A_{i}+\gamma_{5} A_{i}+\gamma_{6} A_{i}^{2}+\gamma_{7} A_{i}^{3}+\eta_{i}
\end{gathered}
$$

Not surprisingly in light of Figure 2, the instruments have considerable predictive power in this model. In a specification that includes a third order polynomial in the assignment score and a full set of controls - capturing demographic and socio-economic characteristics as well as attainment at age 7 and 9 - the F-statistics associated with a test that the excluded instruments have no explanatory power is 287.1 for men and 756.8 for women. To see why the instruments have more predictive power for women, recall that individuals are treated if they attended elite state or private schools and that private school attendance was higher among men. Since the instruments are based on the rules governing assignment to elite state schools, it is not surprising that they have more predictive power for women. Nevertheless, according to conventional critical values (Stock and Yogo, 2005), the values of the F-statistics are high for both groups and we can easily reject the hypothesis that the instruments have no explanatory power. ${ }^{21}$

\footnotetext{
${ }^{21}$ The instruments have even less predictive power for men if we define the treatment as "elite school only" (the F-statistics becomes 214.0). That is because the probability of
} 
For 2SLS estimation based on equations (1) and (2) to generate consistent estimates, the third-order polynomial in assignment scores must capture the underlying relationship between outcomes and this score. We provide three tests of that assumption. First, we check that our estimates are robust to the inclusion of covariates. Since we have an extensive set of covariates (in addition to the assignment scores), this first test should be quite powerful. Second, we conduct falsification tests of the "effect" of elite school attendance on predetermined outcomes such as years of post-compulsory education predicted by all covariates. Third, we check that our estimates are robust to alternative polynomial specifications.

If treatment effects are heterogenous, we expect our strategy will identify treatment effects for borderline students. As discussed in Angrist and Pischke (2009), the interpretation of 2SLS estimates is more complicated in the presence of multiple instruments (not all of which are binary) and covariates. Nevertheless, the "LATE" interpretation is expected to hold. That is, we expect to identify treatment effects for the students for whom elite school attendance was influenced by the value of these instruments. These students are those with scores in the marginal area (as opposed to students that would - or would not - attend elite schools irrespective of their assignment scores).

Our approach has much in common with the regression kink design (Card et al., 2012; Dong, 2013). Indeed, we produced kinked regression estimates, but these were highly imprecise. ${ }^{22}$ Since our samples are relatively small and the two kinks relatively "close", it is difficult to determine the shape of the relationship between outcomes and the assignment score around the kinks. Our IV stratregy imposes stronger assumptions (e.g., on the outcome-score relationship across the full range of scores) and uses all of the data to help identify the effects of interest. Our approach can therefore be seen as a heavily

attending elite school is declining over high values of the assignment score as the probability of attending private school is increasing sharply in that range (as shown in Appendix A Figure 1). The second-stage results obtained using this definition of the treatment (available upon request) are very similar to those presented here.

${ }^{22}$ These estimates can be found in an earlier working paper version of this paper (Clark and Del Bono, 2014). 
parametrized regression kink design.

\section{Long-term effects of elite school attendance}

We now use the empirical strategy described above to estimate the causal effects of attending an elite school on long term outcomes such as completed education, income, earnings, marriage and fertility. These estimates are obtained separately for men and women. We then pool men and women and report some of the main findings separately by low and high socio-economic status.

\section{Educational attainment}

Table 2 reports estimates of elite school effects on three measures of educational attainment. Our main measure (top panel) is the number of completed years of full-time education beyond the compulsory school leaving age (i.e., age left school plus years of full-time higher education less the compulsory schooling age facing these cohorts, i.e., 15). In using this measure we follow the labor economics literature and assume that there are constant returns to additional years of completed education (Card, 2001). We also consider A-level equivalent qualifications obtained at age 17 (middle panel) and degree or higher level qualifications (bottom panel). ${ }^{23}$ For each of these outcomes we report least squares estimates (columns 1-2 and 5-6 for men and women, respectively) and 2SLS estimates (columns 3-4 and 7-8). In columns 1 and 5 our specifications include only a dummy for attending an elite school; all other specifications include a third-order polynomial in the assignment score; in columns 2, 4, 6 and 8 we also include a set of covariates that take into account individual differences in demographic characteristics, socio-economic characteristics, and previous attainment.

\footnotetext{
${ }^{23}$ In a previous version of this paper we analyzed a larger number of qualifications. To streamline the analysis we focused on A levels and degrees. Apart from $\mathrm{O}$ levels (for which we found no effects), these are arguably the better-known qualfications.
} 
Table 2 shows that, on average, relative to non-elite school male students, elite-school male students completed more than three additional years of fulltime education (column 1). After controlling for covariates and a third-order polynomial in the assignment score, this is 1.6 years. The 2SLS estimates are smaller than this, although statistically not different, and show an estimated effect of about one year of additional full-time education. This is a very large effect. For example, if we consider that borderline male students that attended a non-elite school completed an average of 1.99 years of post-compulsory schooling (the "control mean"), our preferred estimate (2SLS without covariates) implies that elite school attendance increased years of post-compulsory education by over 50 percent.

The results for women are qualitatively similar. As reported in Table 2, on average, women that attended elite schools completed around 2.93 additional years of full-time education (column 5). After controlling for assignment scores and other covariates, the estimated effect is 0.74 years. The 2SLS estimates are consistent with these numbers, ranging from 0.79 (column 7) to 0.67 (column 8 ) years. Since the control mean for women is 2.3 years, the implied effect size is about 35 percent.

Figure 3 provides visual evidence of positive elite school effects on this outcome. The graphs in this Figure superimpose the fitted values from reducedform models on a scatterplot of the outcome means over 10-points intervals of the assignment score. The defining characteristic of the first-stage relationship (Figure 2) is that the fitted probability of treatment increases sharply over the marginal area. As such, if treatment effects are positive, we would expect the fitted reduced-form relationship to be steeper over the marginal area. This is indeed what we see in Figure 3. Note that we would not expect the graphs in Figure 3 to take exactly the same shape as those in Figure 2, as the former will also reflect a generally positive relationship between outcomes and assignment scores. Our estimates pass three robustness checks. First, they are robust to the inclusion of covariates (see columns 3 and 4 and columns 7 and 8 of Table 2). Second, they suggest that elite school attendance has no "effect" on pre-determined outcomes. This can be seen in Figure 4, which depicts the 
elite school "effect" on a pre-assignment test score (taken at age 9). It can also be seen in the first panel of Appendix A Table 2, which reports the estimated effect on years of post-compulsory schooling predicted using the extensive set of background characteristics available in our data. ${ }^{24}$ Third, our estimates are similar to those derived from models that use different polynomial specifications (see Appendix A Table 3).

The remaining panels of Table 2 report education impacts on A levels and degrees. For men, the main impacts of elite school attendance are to increase the probability of achieving A-level qualifications (by about 10 percentage points) and degree receipt (by 17 percentage points). The latter effect is more than double the control group mean. For women, elite school attendance is shown to increase the probability of obtaining A-level qualifications or equivalent by around 23 percentage points - or 56 percent of the control group mean. There is no apparent impact on degree receipt.

With our discussion of the relevant institutions in mind, these large effects on educational attainment are perhaps not surprising. As we noted, the path to a university degree was longer and harder for non-elite school students. For example, the non-elite schools were unlikely to offer many university-appropriate courses and transfer to elite schools was uncommon. In addition, since few non-elite school students attended university, default behavior and peer effects may have pushed students away from this path. We suspect that these institutional barriers facing students that attended non-elite schools in the 1960s hold the key to understanding why we estimate larger education effects than those found in other studies (e.g., Dobbie and Fryer, 2011; Dustmann et al., 2012).

\footnotetext{
${ }^{24}$ By contrast, even the OLS estimates with all controls suggest an impact of elite school attendance on the predicted outcome. This highlights the importance of dealing with omitted variables bias in the OLS estimates.
} 


\section{Labor market outcomes}

Table 3 reports estimates of elite school effects on gross annual income, employment, and imputed gross hourly wages. Gross annual income and employment are measured at the time of the 2001 survey, when respondents were aged between 46 and 51. The income measure includes "personal current gross income from all sources", including interest from dividends and benefits, and is expressed in banded intervals. We impute gross hourly wages using occupationspecific means of hourly gross wages from the New Earnings Survey (NES). ${ }^{25}$

Given the large effects on education documented above, we might expect elite school attendance to generate significant impacts on income and wages. In fact, both our adjusted OLS and 2SLS point estimates suggest that for men, elite school attendance had no significant effects on annual income, hourly wages or the probability of employment. For income the point estimates are negative (consistent with the shape of Figure 4) although so imprecisely estimated that we cannot rule out positive wage effects commensurate with typical estimates of the returns to a year of education (e.g., 5-6 percent - Card, 2001). ${ }^{26}$ In the next section we discuss what might account for these puzzling findings. For now, we note that the 2SLS estimates pass all of our robustness checks. In particular, models with covariates generate similar estimates (columns 3 and 4) and falsification checks do not reveal any impact of elite school attendance on measures of income predicted using control variables (Appendix A Table 2). Although the estimates appear to be somewhat sensitive to the order of the polynomial in assignment scores (Appendix A Table 3), in general they remain statistically indistinguishable from zero.

\footnotetext{
${ }^{25}$ In order to compute occupation-specific earnings we take the period between 1997 and 2001 and restrict the sample to individuals working in Scotland and aged 45-55. The imputation of the earnings variables is based on 2-digit SOC 1990 classification. We would like to thank Annarosa Pesole for her help with the NES data.

${ }^{26}$ Income is recorded in 8 bands and a large group of individuals, especially men (about 20 percent), fall in the top interval. We produced several estimates of the impact of elite school attendance on the probability of being in the top interval, but none suggested any impacts. Similarly, we estimated elite school effects using several methods that account for the banded nature of the variable, including interval regression (Stewart, 1983), all of which generated results similar to those reported in the current analysis.
} 
For women, as reported in Table 3, we find that elite school attendance increased annual income by around 15 percent. ${ }^{27}$ This is obviously a large effect, and it can be seen in Figure 5. Although the estimate is again not very precise, and is somewhat sensitive to the order of the polynomial (Appendix A Table 3 ), it is very robust to the inclusion or exclusion of the covariates. An obvious question is whether the effect for women is driven by increased hourly wages, increased labor supply or some combination of the two. Our results suggest that both effects could be at work. On the one hand, we estimate elite school effects on hourly wages of around 7 percent (Table 3, bottom panel). On the other hand, this alone cannot account for the large increase in annual income, so labor supply impacts seem likely. Although we find no elite school effects on whether women worked at all (middle panel in Table 3), this does not preclude effects on hours worked. Unfortunately, we do not have data on hours worked so we cannot examine this possibility.

\section{Fertility and marriage}

For men, the estimates reported in Table 4 suggest no obvious effects of elite school attendance on fertility and marriage outcomes. Since we found that elite school attendance had no impact on labor market outcomes, this is perhaps not surprising. One possible caveat to this summary is the suggestion of a positive elite school effect on the number of children (top panel), although the estimates are sensitive to the inclusion of covariates and much lower when these are excluded. The magnitude of this effect is also sensitive to the polynomial specification. It is also interesting that the unadjusted OLS estimates for these outcomes are small and statistically indistinguishable from zero.

For women, the estimates reported in Table 4 suggest that elite school attendance decreased the probability of having any children and decreased total

\footnotetext{
${ }^{27}$ An obvious point of comparison is the effects of the British compulsory schooling reforms. Yet, estimates of the 1947 and 1972 reforms provide conflicting evidence as to whether or not women's wages increased: Devereux and Hart (2010) estimate zero returns for the 1947 reform; Grenet (2013) estimates much larger effects of the 1972 reform (about 6 percent).
} 
fertility, although they do not reveal any obvious effects on the probability of being married or on the timing of fertility (not reported). ${ }^{28}$ As seen in Appendix A Table 3, the estimates are somewhat sensitive to the polynomial specification, although all the point estimates suggest fertility reductions of at least 0.3 children. In our view, a reasonable conclusion is that elite school attendance decreased fertility for women and that these effects were potentially large. Since we found that elite school attendance increased women's hourly wages and annual income, an effect on fertility is less surprising. As noted by Becker (1960) and Willis (1973), higher earnings power increases the opportunity costs of having children and will thereby decrease fertility. ${ }^{29}$

\section{Discussion and Interpretation}

There is an obvious explanation for the direction of the women's results: elite school attendance makes further education more attractive (by reducing its costs or increasing its returns), such that elite school attendance increases completed education and thereby labor market productivity and incomes. Higher wages also increase the opportunity costs of having children, such that elite school attendance reduces completed fertility. But even if the direction of the effects is as expected, the magnitude of the estimates is strik-

\footnotetext{
${ }^{28}$ On marriage, Lefgren and McIntyre (2006) use the quarter-of-birth instrument and find "suggestive" evidence of small effects. It is also possible that assignment to an elite school improved the quality of the partner (measured by test scores or education achieved) because it gave access to a different marriage market. This hypothesis is investigated in Kaufmann et al. (2013), who consider the returns to attending an elite university in Chile. Unfortunately, our data does not have any information on the characteristics of the partner.

${ }^{29}$ We also looked at whether the estimates differ by socio-economic status (SES), which would be the case if elite schools were especially helpful in taking low-SES students out of home and peer environments not conducive to educational success (see Clark, 2010). To that end, we split our sample into low- and high-SES subsamples and looked at the effect of elite school attendance on all our outcomes. The estimates, reported in Appendix A Table 4 , show that elite school attendance did not have markedly different impacts on low- and high-SES individuals. While this may seem surprising at first glance, it is less striking once we realise that for education outcomes, the low-SES and high-SES control means are quite similar. This suggests that among borderline students that attended non-elite schools, the socio-economic gap in outcomes was small. With this in mind, it is less surprising that effects appear not to differ by SES.
} 
ing. In particular, our results suggest effects on completed fertility of almost 0.4 children per woman, or a decrease of about 40 percent with respect to the mean.

Since elite school attendance increased completed education, these estimates may reflect the causal effect of women's education on these outcomes. If so, they imply that these causal effects are larger than existing estimates suggest. To be more specific, as the estimated impact of elite school attendance on education is of the order of 0.8 years of schooling (Table 2, and Appendix Table A 3), our analysis would imply an income return to one extra year of schooling of about 10 percent, and a fertility response of almost 0.5 children per woman. As noted in the Introduction, studies of the income and fertility returns to education for women are typically based on compulsory schooling reforms. This suggests at least two explanations for the difference between those estimates and ours. First, education may have different effects on the types of students affected by compulsory schooling reforms (i.e., those that would otherwise drop out of school) than on the types of students affected by elite school attendance (i.e., those around the 80th percentile of the age-11 ability distribution). ${ }^{30}$ Second, they might be explained by other dimensions of the elite schools quasi-experiment. Most obviously, placing girls in an elite school environment with other high-achieving girls may change their perceptions of women's role in society and their decisions regarding career, marriage and family. Although it is not possible for us to provide hard evidence of this mechanism, our analysis underlines the importance of additional research into the effects of women's education on these outcomes.

The men's results are harder to explain, particularly our finding that elite school attendance increased completed education by about one year but had no significant impact on incomes or wages. Note first that our estimates are somewhat imprecise, such that we cannot quite rule out effects comparable

\footnotetext{
${ }^{30}$ Another explanation centers on differences in the content of the education provided (e.g., whether schools provided information on birth control), but there is little we can do to assess this. The time period studied is unlikely to explain the difference, since the second UK compulsory schooling reform studied by Grenet (2013) and Geruso and Royer (2014) affected individuals born only a few years after those that we study.
} 
to conventional estimates of the return to a year of completed education (510 percent). This imprecision may be due in part to the "banded" nature of income, which likely affects the estimates for men more than estimates for women. This caveat aside, one possible explanation is that this generation of men enjoyed many vocational training options, especially trade apprenticeships, and that positive elite school effects on further education were offset by negative elite school effects on vocational training. Although we do not have the vocational training or apprenticeship data necessary to provide a direct test of this hypothesis, several facts are consistent with this story.

First, as seen in Appendix B Table 3, other data (Labour Force Survey (LFS) data) suggest that a large fraction of Scottish-born men of this generation completed an apprenticeship. The overall percentage is close to 40 percent and the percentage among men with some additional qualifications is even higher. Since our sample control means suggest that borderline men that attended non-elite schools typically had additional qualifications, it seems likely that at least one half of them completed a trade apprenticeship.

Second, simple economic reasoning suggests that elite school attendance likely decreased the probability of completing an apprenticeship. We set out a simple model to this effect in Appendix C; this extends the Card and Krueger (1996) model of school quality to include vocational training. We show that under some assumptions, elite school attendance could decrease the quantity of vocational training completed and could thereby decrease wages. The first key assumption is that elite school attendance increases the returns to academic education, decreases the costs of academic education and increases the cost of vocational training. The second key assumption is that while the returns to academic education are higher than the returns to vocational education, the relative return to vocational training is higher than the relative return to academic education. Both sets of assumptions seem reasonable, the second one because it generates a natural partition of students into those that leave school without further education or training, those that pursue vocational training and those that pursue academic education. This theoretical reasoning is supported by estimates of the elite school impact on years of part-time 
post-compulsory education completed (not reported but available on request). These suggest that elite school attendance decreased part-time years completed by roughly 0.6 (almost 40 percent of the mean). Since vocational training typically includes a part-time education component, these estimates are consistent with elite school attendance reducing vocational training.

Third and most compelling, neither of these facts applies to women, for whom we did find some evidence of positive elite school effects on income. The statistics reported in Appendix B Table 3 suggest that far fewer women completed apprenticeships, and for women we find little elite school impact on years of part-time education completed.

The fourth fact is derived from a testable prediction of the model that we present in Appendix C, namely, that the presence of vocational training will lower the returns to completed education. The intuition is that in addition to the usual (positive) "ability bias" component of the measured return (i.e., a positive correlation between academic education and ability), there will be an additional (negative) "vocational training bias" component (i.e., a negative correlation between academic education and vocational training). As seen in Appendix B Table 4 column 1, we do indeed find measured returns to be much larger for women than for men. This is consistent with other (OLS) estimates found in the UK literature (e.g., Grenet 2013; Devereux and Hart 2010), which reveal a gender gap of similar magnitude.

Although we think that this vocational training hypothesis is both plausible and consistent with the facts, we recognize that it rests on important assumptions and leaves some questions unanswered. One important assumption is that elite school education increases the costs of vocational training. Were this not the case, we would expect elite school attendance to increase men's income and wages. One additional question is why the gender differences associated with the extra education induced by elite school assignment are not found in analyses of the extra education induced by the British compulsory schooling laws (e.g., Grenet, 2013). An explanation consistent with the vocational training explanation for our findings here is that for the men affected by the compulsory schooling reforms there was no displacement of vo- 
cational training. In analyses not reported here, we used the UK 2011 Census to examine whether the men affected by 1947 and 1972 compulsory schooling reforms were less likely to pursue apprenticeship training (the most common form of vocational training at the time). We find no evidence that they were. A second and more obvious explanation is that the effects of education might depend on the type of students and the types of courses involved. For example, education might have larger effects on the lower-ability men affected by the compulsory schooling reforms than on the higher-ability men affected by elite school. Alternatively, there might be larger returns to the lower-level courses (e.g., CSEs) pursued by individuals affected by the compulsory schooling laws than to the higher-level courses (e.g., A levels) pursued by individuals affected by elite schooling.

There are several alternative explanations for our finding that elite school attendance did not increase income and wages for men. First, the result could be an artefact of the sample studied. For example, one can hypothesize that the wage distribution in Aberdeen has been compressed by the oil industry that emerged in the 1970s. To check that, we compared the returns to education estimated using the Aberdeen data with the returns estimated using LFS data (Appendix B Table 4). When we measure education using years of post-compulsory schooling, the estimates are remarkably similar: 0.072 versus 0.069. They are also fairly close when we disaggregate into several education categories. Importantly, there is no evidence to suggest that Aberdeen-UK differences are larger among men than among women. For this reason, we doubt this can explain our results. ${ }^{31}$

Second, one might wonder whether the returns are low because they are estimated for borderline men; perhaps the returns to elite school attendance are higher among higher-scoring men that were in a better position to benefit from the elite school experience. Against that, it is not obvious that elite school effects should be smallest for borderline students, and Angrist and Rokkanen

\footnotetext{
${ }^{31} \mathrm{~A}$ simple way to test this hypothesis would be to look at the fractions of workers employed in the oil industry. Unfortunately, information about industry was not asked of the respondents to the $2000 / 01$ questionnaire.
} 
(2012) find no evidence to suggest they are smaller for borderline students than for higher-scoring students (albeit in a different context). More persuasively in our view, it is hard to reconcile this explanation with our findings for women, which are also identified off the borderline group.

One could reconcile the borderline explanation and the women's results by noting that some elite schools were single-sex and by speculating that a single-sex experience benefited girls more than boys. As an indirect test of this hypothesis, we examined whether the returns to single-sex schools are larger for girls than boys. Least squares estimates based on models that are restricted to single-sex elite school students and that include the full set of covariates provide no support for this hypothesis.

In summary, while we cannot provide a decisive test of the vocational training explanation (without vocational training data), we find it to be plausible and we think it is consistent with some key facts. Since these facts undermine the most obvious alternative explanations, we view the vocational training hypothesis as the leading explanation for our results.

\section{Conclusion}

What is the causal effect of being assigned to an elite secondary school in a selective school system? The balance of the existing evidence suggests small impacts on short- and medium-run outcomes such as high school test scores and college enrollment and attainment. In this paper we estimate the effects of elite school attendance on long-run outcomes such as completed education, income, wages, marriage and fertility. We find that, on average, elite school attendance caused both men and women to complete almost one additional year of full-time education. Surprisingly, however, we do not find strong evidence that these educational impacts translated into stronger labour market performance. With the exception of an imprecisely estimated positive effect on female income, we cannot reject the hypothesis that elite school attendance had no impact on a variety of labour market outcomes. By contrast, we document large and statistically significant negative effects on fertility for women, while we cannot exclude positive effects on male fertility. 
These results support a claim made in the 1950s and 1960s by opponents of selective schooling, that important long-run outcomes could depend, via the elite school assignment decision, on how well a student performed on a single test taken at age eleven. Proponents of selective schooling did not claim that elite school assignment had no impact, but rather that the assignment mechanism was generally reliable, and that selective schooling helped both high-ability students stretched by elite schooling and lower-ability students properly catered to by non-elite schooling. Although the debate surrounding selective versus non-selective schooling is interesting and important, our study does not address it. ${ }^{32}$ Instead, our study has tried to assess whether elite school attendance improved outcomes for borderline students, the only students for whom we can credibly identify effects.

In our view, it is difficult to explain our results without invoking various features of the relevant education and labor market institutions. For example, we argued that the large impacts on years of education likely reflect the barriers that faced non-elite school students wishing to pursue further academic education, while we speculated that our labour market results might reflect the choice these cohorts faced between pursuing academic education and vocational training. The role that these institutions might have played provides an obvious explanation for why some of our estimates differ from those found in the previous literature (e.g., Dobbie and Fryer, 2011). These institutions also imply that some of our results may be specific to the time period studied. For example, since the apprenticeship system became much less important after the mid-1970s, it is possible that labor market impacts may have been larger for men educated in the late mid-1970s and beyond.

Our final point is that policy-makers might be advised to keep these institutions in mind when designing policies relating to school resources and organization, including policies relating to elite schools. For example, in the contemporary US context, there is compelling evidence to suggest that college outcomes are affected by whether or not students have access to Advanced

\footnotetext{
${ }^{32}$ See Galindo-Rueda and Vignoles (2004) for an account of the debate surrounding elite schools in the UK during the 1960s.
} 
Placement (AP) courses (Klopfenstein, 2004; Jackson, 2010) and SAT-taking opportunities (Bulman, 2013; Goodman, 2012) in high school. If non-elite school students in district A can take a wide range of AP courses and must sit the SAT by default, while non-elite school students in district B can take only a few AP courses and must travel to another high school to sit the SAT, we might expect elite school attendance to have a smaller impact in district A than district B. It follows that a district that wishes to expand elite schools might also want to ensure that these related policies and institutions are favorable to non-elite school students. 


\section{References}

Angrist, J. and J. Pischke (2009), Mostly Harmless Econometrics: An Empiricist' Companion, Princeton University Press.

Angrist, J., Pathak, P. and C. Walters (2011), Explaining Charter School Effectiveness, NBER Working Paper No. 17332.

Angrist, J., and M. Rokkanen (2012), Wanna Get Away? RD Identification Away from the Cutoff, NBER Working Paper No. 18662.

Batty, G., Morton, S., Campbell, D., Clark, H., Smith, G., Hall, M., Macintyre, S., and D. Leon (2004), The Aberdeen Children of the 1950s Cohort Study: Background, Methods, and Follow-up Information on a New Resource for the Study of Life-Course and Intergenerational Effects on Health, Paediatric and Perinatal Epidemiology, 18: 221-239.

Becker, G. (1960), An Economic Analysis of Fertility, in Demographic and Economic change in Developed Countries, Universities-National Bureau of Economic Research Conference Series 11. NBER: Princeton, NJ, 209-231.

Black, S., Devereux, P. and K. Salvanes (2008), Staying in the Classroom and out of the Maternity Ward? The Effect of Compulsory Schooling Laws on Teenage Birth, Economic Journal, 118(530): 1025-1054.

Bulman, G. (2013), The Effect of Access to College Assessments on Enrollment and Attainment, unpublished paper, Stanford University.

Card, D. (2001), Estimating the Return to Schooling: Progress on Some Persistent Econometric Problems, Econometrica, 69: 1127-60.

Card, D. and A. Krueger (1996), Labour Market Effects of School Quality: Theory and Evidence, NBER Working Paper No. 5450.

Card, D., Lee, D., Pei, Zhuan, and A. Weber (2012), Nonlinear Policy Rules and the Identification and Estimation of Causal Effects in a Generalized Re- 
gression Kink Design, NBER Working Paper No. 18564.

Clark, D. (2010), Selective Schools and Academic Achievement, the B.E. Journal of Economic Analysis and Policy, 10(1): 1935-1682.

Clark, D. and E. Del Bono (2014), The Long-Run Effects of Attending an Elite School: Evidence from the UK, IZA Discussion Paper n.8617.

Cullen, J.B., Jacob, B. and S. Levitt (2006), The Effect of School Choice on Participants: Evidence from Randomized Lotteries, Econometrica, 74(5): 1191-1230.

Currie, J. and E. Moretti (2003), Mother's Education and the Intergenerational Transmission of Human Capital: Evidence from College Openings, Quarterly Journal of Economics, 118(4): 1495-1532.

Deming, D. (2010), Better Schools, Less Crime?, Quarterly Journal of Economics, 126(4): 2063-2115.

Devereux, P. and D. Hart (2010), Forced to be Rich? Returns to Compulsory Schooling in Britain, Economic Journal, 120: 1345-1364.

Dobbie, W. and R. Fryer (2011), Exam High Schools and Academic Achievement: Evidence from New York City, NBER Working Paper No. 17286.

Dong, Y. (2013), Regression Discontinuity without the Discontinuity, unpublished paper, University of California, Irvine.

Duflo, E., Dupas, P. and M. Kremer (2011), Peer Effects, Teacher Incentives, and the Impact of Tracking: Evidence from a Randomized Evaluation in Kenya, American Economic Review, 101(5): 1739-74.

Dustmann, C., Puhani, P. and U. Schönberg (2012), The Long-term Effects of School Quality on Labor Market Outcomes and Educational Attainment, CReAM Discussion Paper Series 1208, Department of Economics, University College London. 
Findlay, I. (1973), Education in Scotland, World Series in Education. David and Charles: Newton Abbot.

Galindo-Rueda, F. and A. Vignoles (2004), The Heterogeneous Effect of Selection in Secondary Schools: Understanding the Changing Role of Ability, IZA Discussion Paper n. 1245.

Garces, E. and J. Currie, J. and D. Thomas (2002), Longer-term effects of Head Start, American Economic Review, 92(4): 999-1012.

Geruso, M. and H. Royer (2014), The Impact of Education on Family Formation: Quasi-Experimental Evidence from the UK, mimeo, University of California, Santa Barbara.

Goldin, C. (2006), The quiet revolution that transformed women's employment, education, and family, American Economic Review, 96: 1-21.

Goldin, C., Katz L.F. and I. Kuziemko (2006), The Homecoming of American College Women: The Reversal of the Gender Gap in College, Journal of Economic Perspectives, 20: 133-156.

Goodman, S. (2012), Learning from the Test: Raising Selective College Enrollment by Providing Information, unpublished paper, Columbia University.

Grenet, J. (2013), Is Extending Compulsory Schooling Alone Enough to Raise Earnings? Evidence from French and British Compulsory Schooling Laws, Scandinavian Journal of Economics, 115(1): 176-210.

Guyon, N., Maurin, E. and S. McNally (2012), The effect of tracking students by ability into different schools: a natural experiment, Journal of Human Resources, 47(3): 684-721.

Illsley, R. and F. Wilson (1981), Longitudinal studies in Aberdeen, Scotland. C. The Aberdeen child development survey, in Mednick S., Baert A., Bachmann B. (eds.) Prospective longitudinal research. An empirical basis for the 
primary prevention of psychosocial disorders. Oxford: Oxford Univerity Press. Illsley, R. (2002), A City's Schools: from Inequality of Input to Inequality of Outcome, Oxford Review of Education, 28: 427-445.

Jackson, C. K. (2010), Do students benefit from attending better schools? Evidence from rule-based student assignments in Trinidad and Tobago, Economic Journal, 120(549): 1399-1429.

Jacob, B. and L. Lefgren (2004), Remedial Education and Student Achievement: A Regression-Discontinuity Analysis, Review of Economics and Statistics, 81(1): 226-244.

Kaufmann, K.M., Messner, M. and A. Solis (2013), Returns to Elite Higher Education in the Marriage Market: Evidence from Chile, available at SSRN: http://ssrn.com/abstract=2313369 or http://dx.doi.org/10.2139/ssrn.2313369.

Klopfenstein, K. (2004), The Advanced Placement Expansion of the 1990s: How Did Traditionally Underserved Students Fare?, Education Policy Analysis Archives, 12(68).

Krueger, A. B. and D. Whitmore (2001), The effect of attending a small class in the early grades on college test taking and middle school test results: Evidence from Project STAR, Economic Journal, 111(468): 1-28.

Lefgren, L. and F. McIntyre, 2006, The Relationship between Women's Education and Marriage Outcomes, Journal of Labor Economics, 24(4): 787-830.

Monstad, K., Propper, C. and K. Salvanes (2008), Education and Fertility: Evidence from a Natural Experiment, Scandinavian Journal of Economics, 110(4): 827-85.

Pop-Eleches, C. and M. Urquiola, (2013), Going to a Better Schools: Effects and Behavioral Responses, American Economic Review, 103(4): 1289-1324.

Steedman, H., Gospel, H. and P. Ryan (1998), Apprenticeship: A Strategy for 
Growth, A Special Report published by the Centre for Economic Performance, London School of Economics and Political Science.

Stewart, M. (1983), On Least-Squares Estimation when the Dependent Variable is Grouped, Review of Economic Studies, 50: 737-753.

Stock, J. and M. Yogo (2005), Testing for Weak Instruments in Linear IV Regression, ch. 5 in J.H. Stock and D.W.K. Andrews (eds.), Identification and Inference for Econometric Models: Essays in Honor of Thomas J. Rothenberg, Cambridge University Press.

Willis, R. (1973), A New Approach to the Economic Theory of Fertility Behavior, Journal of Political Economy, 81: 514-64. 
Figure 1: Distribution of assignment scores
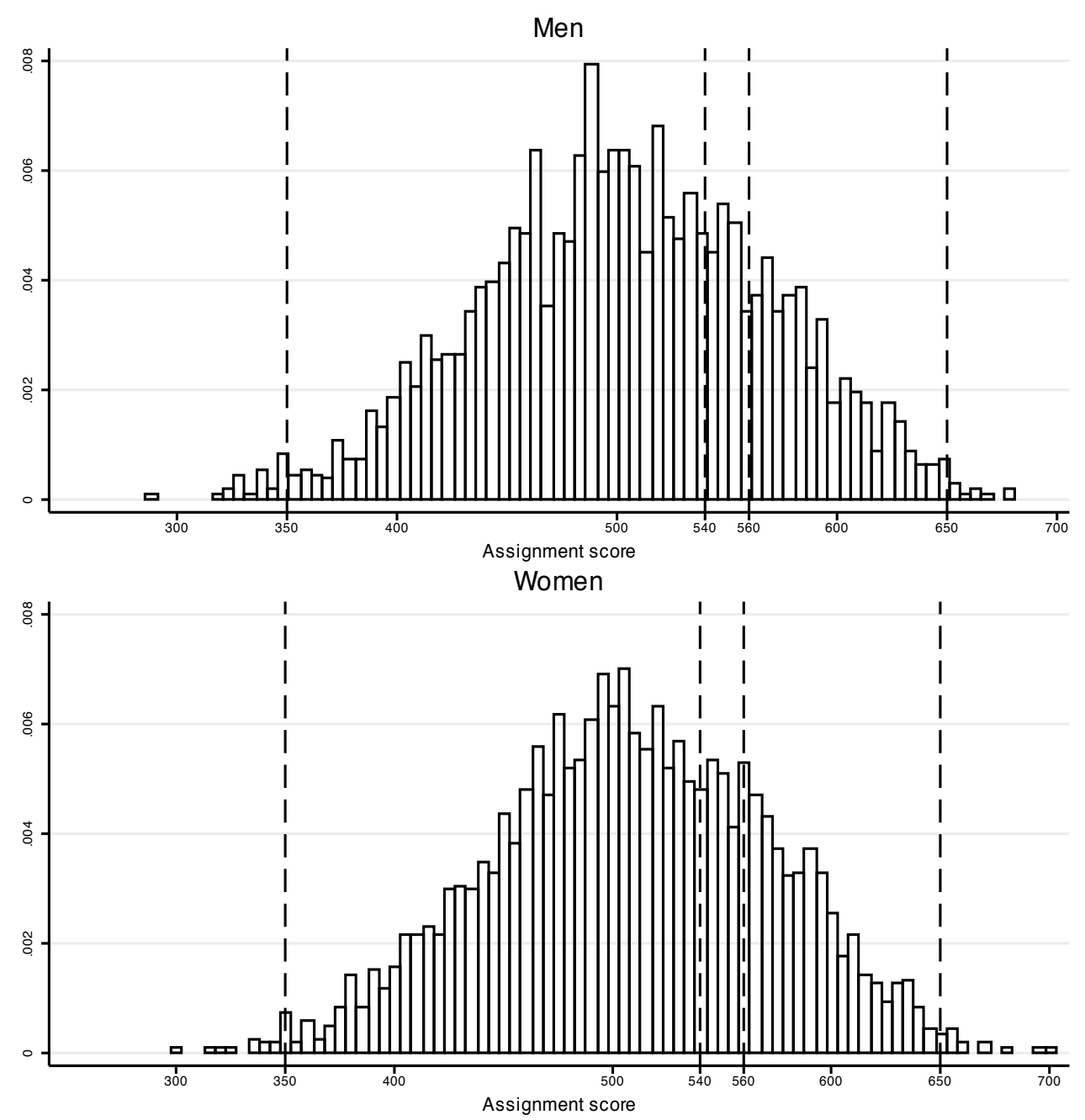

Notes: figures based on "final sample" (see text and Appendix Table 1). Each bar is drawn over an interval defined by 5 values of the assignment score (350-354, etc). Vertical lines plotted at the following score values: $350-354,540-544,560-564$, 650-654. 
Figure 2: Assignment score and the probability of attending an elite school
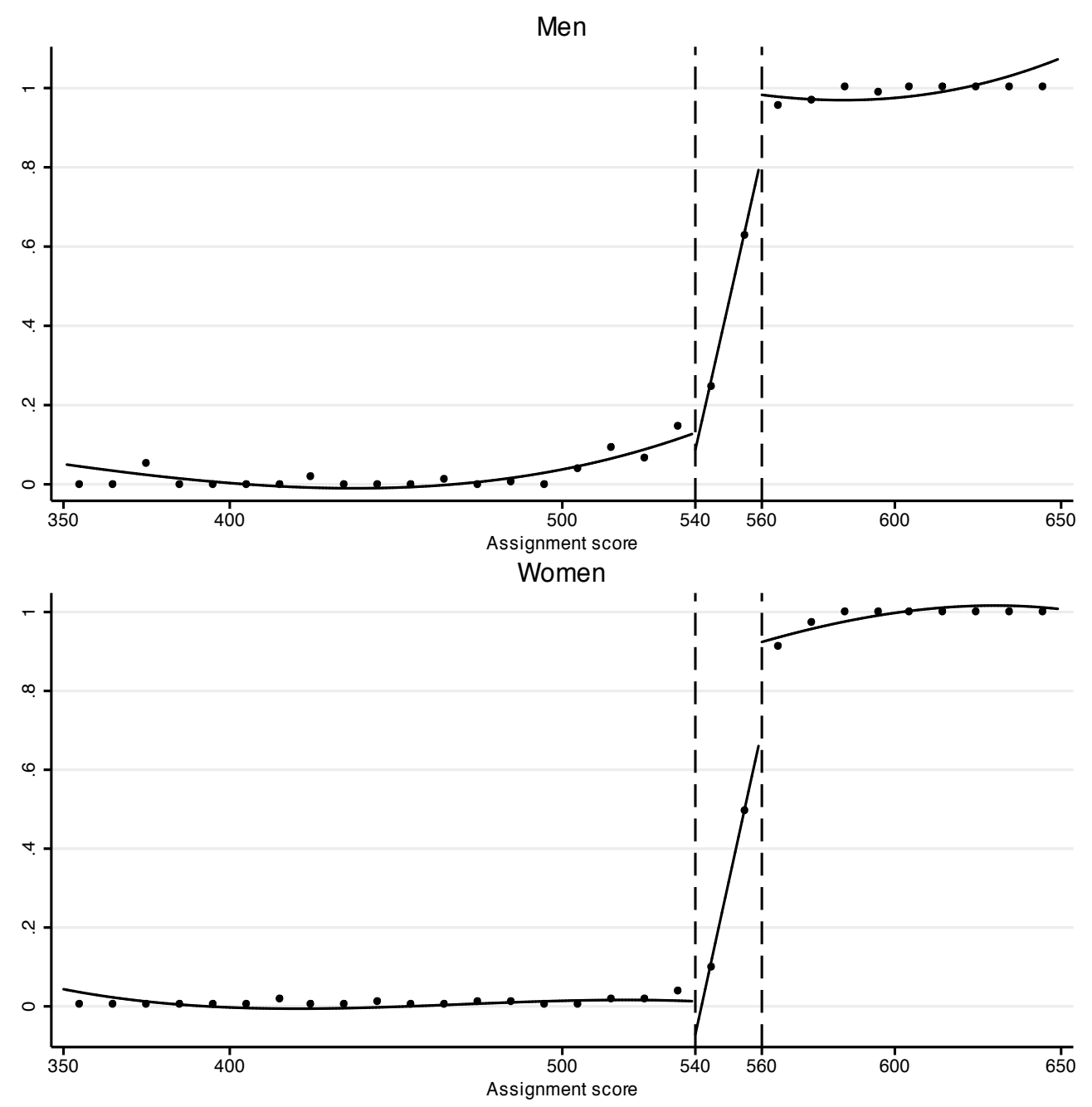

Notes: figure based on "final sample" (see text and Appendix Table 1). Each circle represents the fraction of students in each cell that attended an elite school. Cells defined over 10 values of the assignment score (350-354, etc.). The solid line represents the probability of elite school assignment using the "first stage" model described in the text. 
Figure 3: Assignment score and years of post-compulsory schooling
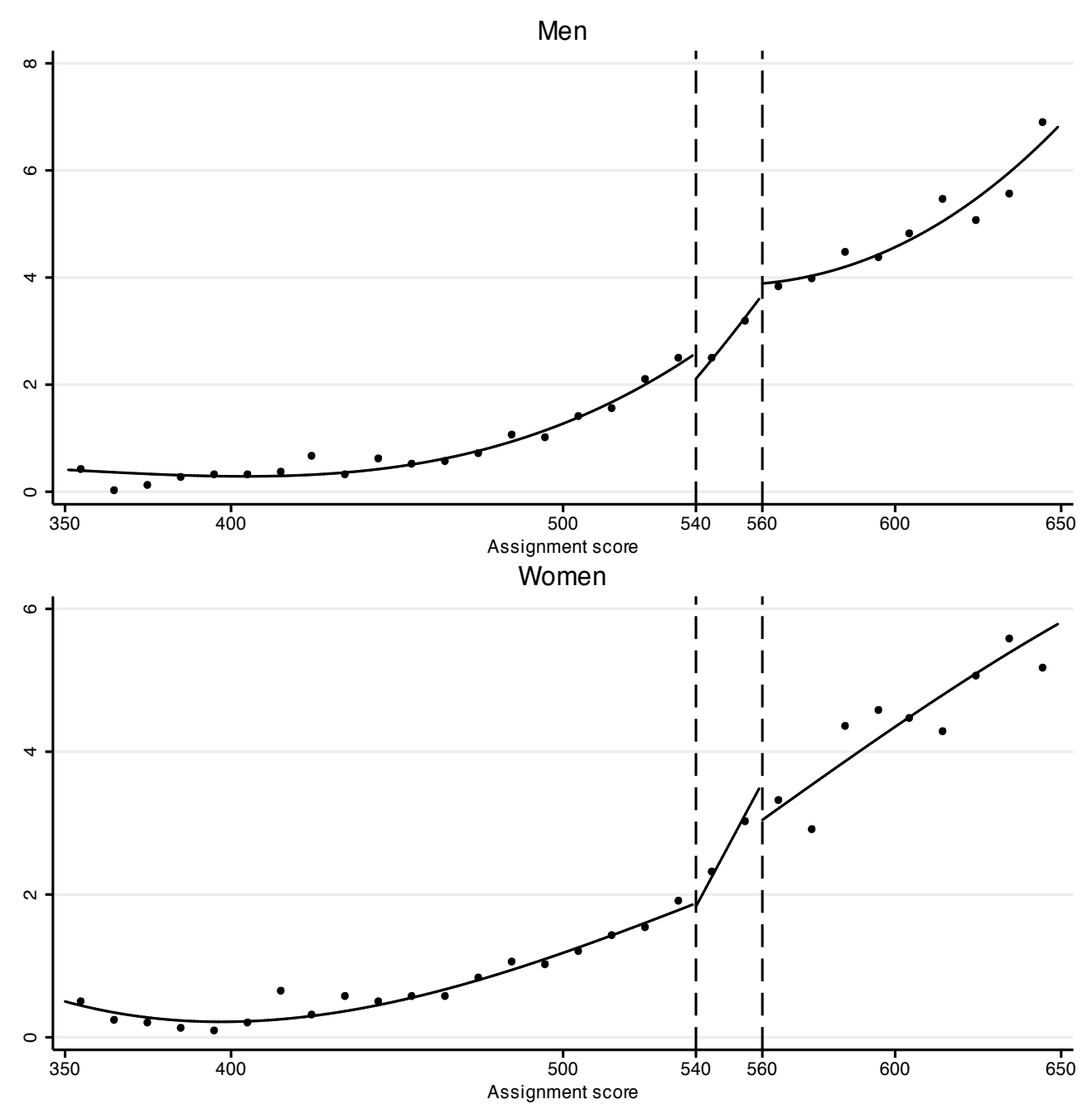

Notes: figure based on "final sample" (see text and Appendix Table 1). The circles are outcome means corresponding to 10-score intervals (350-359, etc.). The solid lines are the fitted outcomes generated by fitting the first-stage model (described in the text and depicted in Figure 2) to this outcome. 
Figure 4: Assignment score and pre-assignment test score at age 9
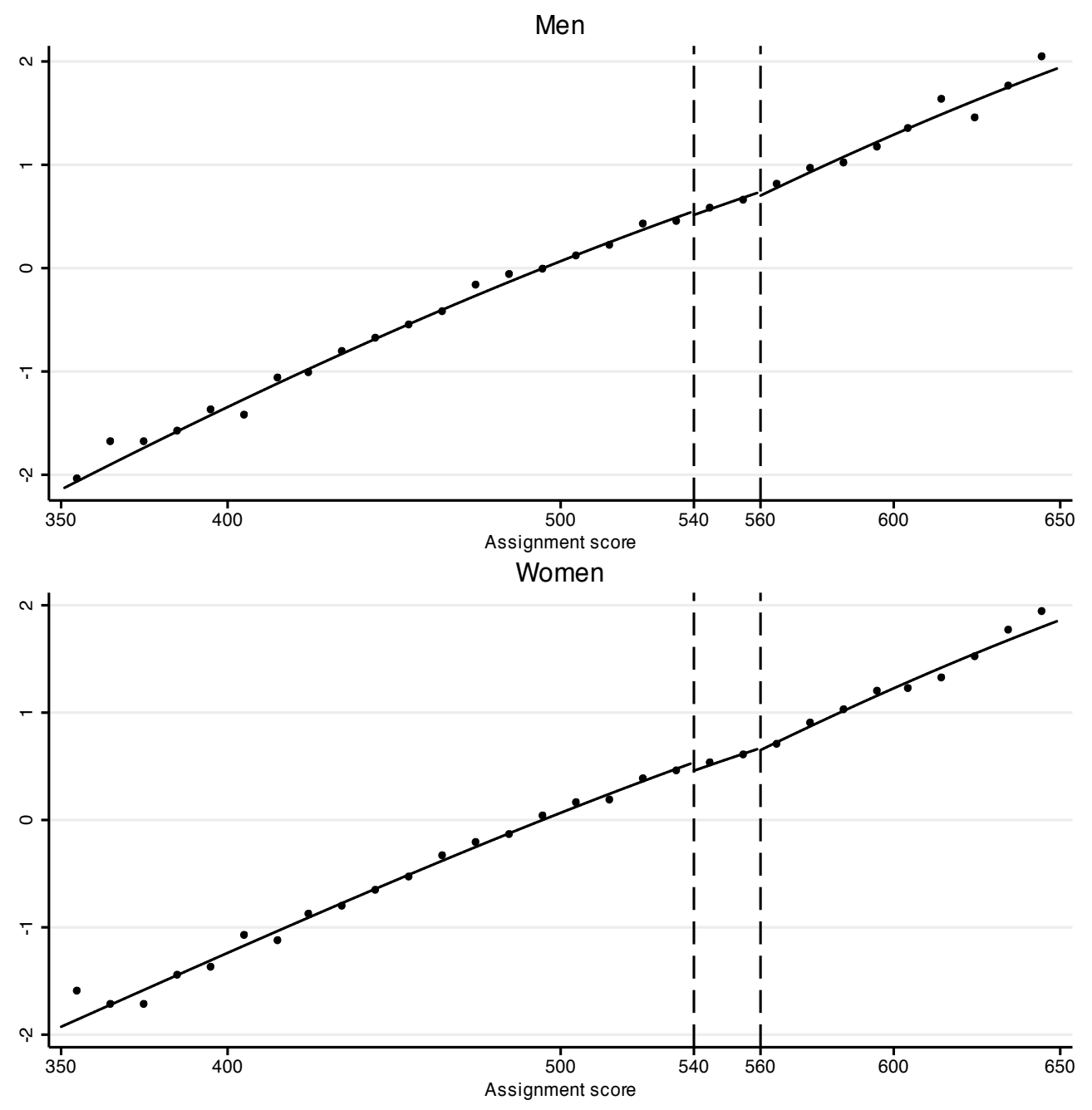

Notes: see notes to Figure 3. 
Figure 5: Assignment score and log annual income
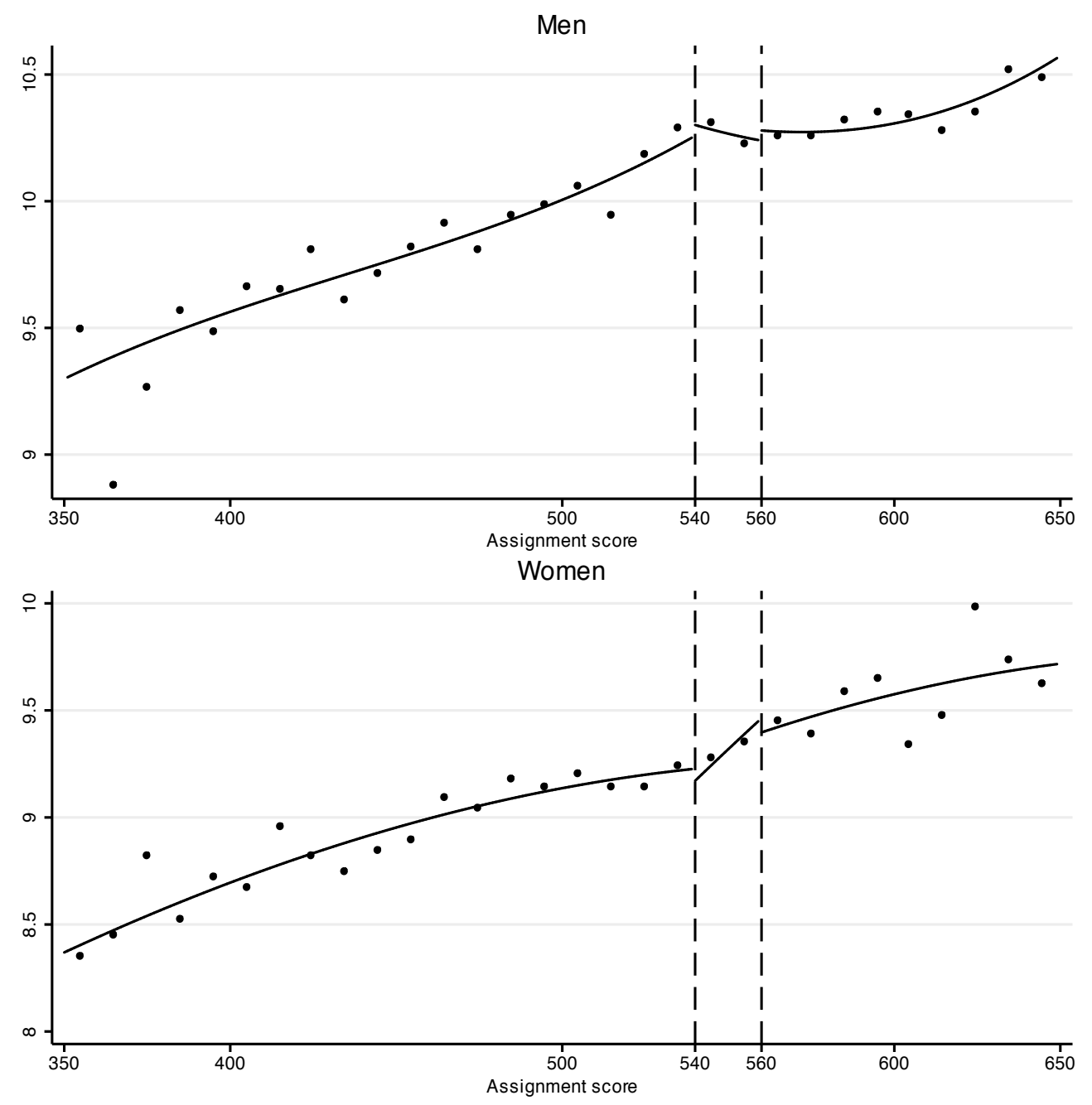

Notes: see notes to Figure 3. 
Figure 6: Assignment score and number of children
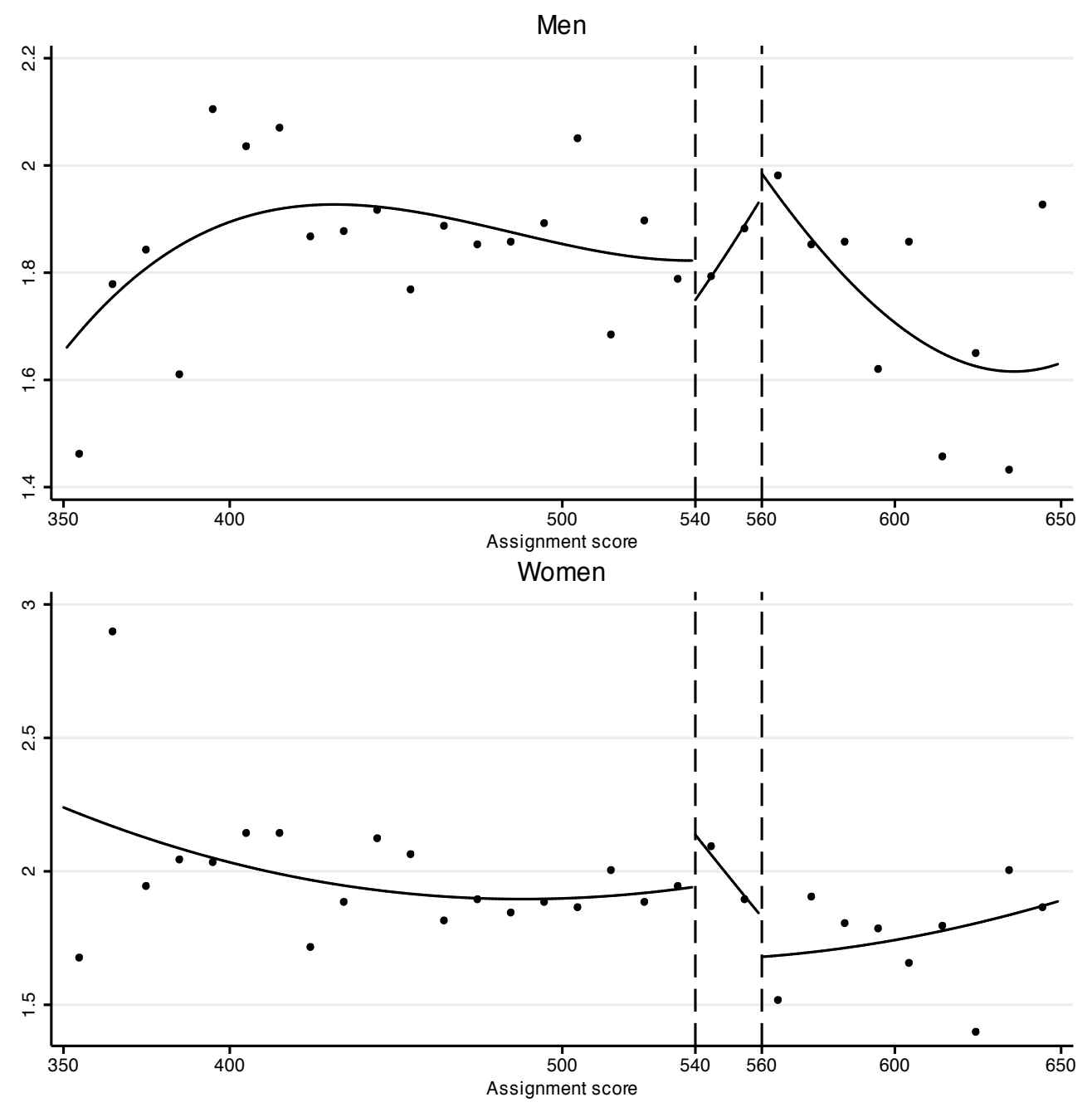

Notes: see notes to Figure 3. 
Table 1: Descriptive Statistics

\begin{tabular}{|c|c|c|c|c|c|c|c|c|}
\hline & \multicolumn{2}{|c|}{ Base sample } & \multicolumn{6}{|c|}{ Final sample } \\
\hline & & & \multicolumn{2}{|c|}{ All } & \multicolumn{2}{|c|}{ Non-elite } & \multicolumn{2}{|c|}{ Elite } \\
\hline & mean & $\mathrm{N}$ & mean & $\bar{N}$ & mean & $\mathrm{N}$ & mean & $\mathrm{N}$ \\
\hline$\overline{\text { Male }}$ & 0.519 & 9893 & 0.483 & 4709 & 0.480 & 3489 & 0.492 & $\overline{1220}$ \\
\hline Age (Dec 1962) & $\begin{array}{c}9.716 \\
(1.441)\end{array}$ & 9893 & $\begin{array}{l}10.216 \\
(1.160)\end{array}$ & 4709 & $\begin{array}{l}10.163 \\
(1.158)\end{array}$ & 3489 & $\begin{array}{l}10.162 \\
(1.158)\end{array}$ & 1220 \\
\hline Father's social class & & 9893 & & 4709 & & 3489 & & 1220 \\
\hline Other (unemployed, disabled, etc.) & 0.052 & & 0.048 & & 0.052 & & 0.039 & \\
\hline Unskilled manual & 0.170 & & 0.157 & & 0.184 & & 0.080 & \\
\hline Semi-skilled manual & 0.148 & & 0.143 & & 0.164 & & 0.083 & \\
\hline Skilled manual, other & 0.208 & & 0.207 & & 0.226 & & 0.155 & \\
\hline Skilled manual, requiring apprent. & 0.252 & & 0.261 & & 0.243 & & 0.311 & \\
\hline Other non manual & 0.108 & & 0.116 & & 0.093 & & 0.181 & \\
\hline Intermediate/Technical & 0.051 & & 0.056 & & 0.033 & & 0.120 & \\
\hline Professional & 0.011 & & 0.012 & & 0.005 & & 0.032 & \\
\hline Grade in 1962 & & 9893 & & 4709 & & 3489 & & 1220 \\
\hline Grade 3 & 0.205 & & 0.000 & & 0.000 & & 0.000 & \\
\hline Grade 4 & 0.204 & & 0.260 & & 0.261 & & 0.256 & \\
\hline Grade 5 & 0.202 & & 0.250 & & 0.252 & & 0.243 & \\
\hline Grade 6 & 0.194 & & 0.247 & & 0.242 & & 0.261 & \\
\hline Grade 7 & 0.195 & & 0.243 & & 0.244 & & 0.239 & \\
\hline Test7 & $\begin{array}{l}-0.020 \\
(0.924\end{array}$ & 9893 & $\begin{array}{c}0.093 \\
(0.899)\end{array}$ & 4709 & $\begin{array}{l}-0.182 \\
(0.797)\end{array}$ & 3489 & $\begin{array}{c}0.878 \\
(0.688)\end{array}$ & 1220 \\
\hline Test9 & $\begin{array}{l}-0.040 \\
(0.955)\end{array}$ & 9893 & $\begin{array}{c}0.098 \\
(0.922)\end{array}$ & 4709 & $\begin{array}{l}-0.235 \\
(0.758)\end{array}$ & 3489 & $\begin{array}{c}1.048 \\
(0.646)\end{array}$ & 1220 \\
\hline Assignment score (grades 4-7) & $\begin{array}{l}495.4 \\
(66.5)\end{array}$ & 8509 & $\begin{array}{c}506.3 \\
(63.94)\end{array}$ & 4709 & $\begin{array}{l}479.1 \\
(48.1)\end{array}$ & 3489 & $\begin{array}{l}584.1 \\
(31.7)\end{array}$ & 1220 \\
\hline Replied to 2001 survey & 0.595 & 9893 & 1 & 4709 & 1 & 3489 & 1 & 1220 \\
\hline Went to private secondary school & 0.040 & 5885 & 0.038 & 4709 & 0 & 3489 & 0.148 & 1220 \\
\hline Elite School & 0.216 & 5885 & 0.221 & 4709 & 0 & 3489 & 0.852 & 1220 \\
\hline
\end{tabular}

Notes: see Appendix Table 1 for derivation of each sample. There are missing assignment scores among some "base sample" students because assignment scores are not available for students in grade 3 in 1962. "Elite" indicates students in elite state schools and private schools. "Non-elite" indicates pupils in all remaining state schools. 
Table 2: Impact of elite school attendance on educational attainment

\begin{tabular}{|c|c|c|c|c|c|c|c|c|}
\hline & \multicolumn{4}{|c|}{ Men } & \multicolumn{4}{|c|}{ Women } \\
\hline & OLS & $\mathrm{OLS}+\mathrm{X}$ & 2SLS & $2 \mathrm{SLS}+\mathrm{X}$ & OLS & $\mathrm{OLS}+\mathrm{X}$ & 2SLS & $2 \mathrm{SLS}+\mathrm{X}$ \\
\hline \multirow{3}{*}{$\begin{array}{l}\text { Years of } \\
\text { education }\end{array}$} & 3.450 & 1.614 & 0.925 & 1.076 & 2.925 & 0.740 & 0.793 & 0.671 \\
\hline & $(0.133)$ & (0.194) & $(0.310)$ & $(0.313)$ & $(0.133)$ & $(0.160)$ & $(0.254)$ & $(0.246)$ \\
\hline & \multicolumn{4}{|c|}{ Control mean $=1.99, \mathrm{~N}=2238$} & \multicolumn{4}{|c|}{ Control mean $=2.33, \mathrm{~N}=2406$} \\
\hline \multirow{3}{*}{ A levels } & 0.542 & 0.220 & 0.105 & 0.121 & 0.602 & 0.248 & 0.229 & 0.197 \\
\hline & $(0.023)$ & $(0.039)$ & $(0.064)$ & $(0.061)$ & $(0.025)$ & $(0.037)$ & $(0.052)$ & $(0.051)$ \\
\hline & \multicolumn{4}{|c|}{ Control mean $=0.46, \mathrm{~N}=2238$} & \multicolumn{4}{|c|}{ Control mean $=0.41, \mathrm{~N}=2406$} \\
\hline \multirow{3}{*}{ Degree } & 0.448 & 0.203 & 0.170 & 0.182 & 0.326 & 0.0447 & 0.0362 & 0.0287 \\
\hline & $(0.024)$ & $(0.034)$ & $(0.056)$ & $(0.054)$ & $(0.024)$ & $(0.032)$ & $(0.042)$ & $(0.042)$ \\
\hline & \multicolumn{4}{|c|}{ Control mean $=0.14, \mathrm{~N}=2238$} & \multicolumn{4}{|c|}{ Control mean $=0.18, \mathrm{~N}=2406$} \\
\hline
\end{tabular}

Notes: the cells contain estimates (robust standard errors clustered by assignment score in parenetheses) of the impact of attending an elite state school or a private school as opposed to attending a non-elite state school on the relevant outcomes. Estimates are produced for four sets of models. "OLS" (i.e., least squares models without additional covariates); "OLS+X" (i.e., least squares models with a full set of covariates including: dummies for school and grade attended in 1962, father's occupation, and mother's socio-economic status; a linear term of age within grade and fourth-order polynomials of test scores at ages 7 and 9.); "2SLS" (i.e., 2SLS models in which elite school attendance is instrumented with a dummy variable that takes the value 1 if the assignment score is in the interval [540,560) and zero otherwise, a dummy variable that takes the value 1 if the assignment score is at least 560 and zero otherwise and interactions of those dummy variables and the assignment score to the right of the marginal area; no covariates except a third-order polynomial in the assignment score); "2SLS+X"(i.e., the same 2SLS models with the additional covariates listed above). The models are estimated on the subset of the "final sample" (defined in the text and Appendix Table 1) with assignment scores in the interval [350,650). "Control mean" refers to outcome mean among individuals with borderline assignment scores $(540,559)$ that attended non-elite schools. 
Table 3: Impact of elite school attendance on labor market outcomes

\begin{tabular}{|c|c|c|c|c|c|c|c|c|}
\hline & \multicolumn{4}{|c|}{ Men } & \multicolumn{4}{|c|}{ Women } \\
\hline & OLS & OLS+X & 2SLS & 2SLS +X & OLS & OLS $+\mathrm{X}$ & 2SLS & $2 \mathrm{SLS}+\mathrm{X}$ \\
\hline \multirow{3}{*}{$\begin{array}{l}\text { Log Annual } \\
\text { Income }\end{array}$} & 0.400 & 0.024 & -0.115 & -0.130 & 0.488 & 0.229 & 0.154 & 0.171 \\
\hline & $(0.032)$ & $(0.051)$ & $(0.081)$ & $(0.082)$ & $(0.041)$ & $(0.079)$ & $(0.098)$ & $(0.102)$ \\
\hline & \multicolumn{4}{|c|}{ Control mean $=10.23, \mathrm{~N}=2200$} & \multicolumn{4}{|c|}{ Control mean $=9.27, \mathrm{~N}=2353$} \\
\hline \multirow[t]{2}{*}{ Employed } & $\begin{array}{c}0.045 \\
(0.013)\end{array}$ & $\begin{array}{l}-0.026 \\
(0.022)\end{array}$ & $\begin{array}{l}-0.041 \\
(0.040)\end{array}$ & $\begin{array}{l}-0.028 \\
(0.039)\end{array}$ & $\begin{array}{c}0.055 \\
(0.017)\end{array}$ & $\begin{array}{c}-0.007 \\
(0.030)\end{array}$ & $\begin{array}{l}-0.010 \\
(0.037)\end{array}$ & $\begin{array}{l}-0.014 \\
(0.040)\end{array}$ \\
\hline & \multicolumn{4}{|c|}{ Control mean $=0.94, \mathrm{~N}=2238$} & \multicolumn{4}{|c|}{ Control mean $=0.87, \mathrm{~N}=2406$} \\
\hline \multirow[t]{2}{*}{$\begin{array}{l}\text { Imputed log } \\
\text { hourly wage }\end{array}$} & $\begin{array}{c}0.373 \\
(0.021)\end{array}$ & $\begin{array}{c}0.087 \\
(0.034)\end{array}$ & $\begin{array}{l}-0.035 \\
(0.056)\end{array}$ & $\begin{array}{l}-0.015 \\
(0.058)\end{array}$ & $\begin{array}{c}0.357 \\
(0.025)\end{array}$ & $\begin{array}{c}0.067 \\
(0.036)\end{array}$ & $\begin{array}{c}0.073 \\
(0.050)\end{array}$ & $\begin{array}{c}0.067 \\
(0.046)\end{array}$ \\
\hline & \multicolumn{4}{|c|}{ Control mean $=2.37, \mathrm{~N}=2003$} & \multicolumn{4}{|c|}{ Control mean $=1.90, \mathrm{~N}=2119$} \\
\hline
\end{tabular}

Notes: see notes to Table 2. 
Table 4: Impact of elite school attendance on fertility and marriage

\begin{tabular}{|c|c|c|c|c|c|c|c|c|}
\hline & \multicolumn{4}{|c|}{ Men } & \multicolumn{4}{|c|}{ Women } \\
\hline & OLS & $\mathrm{OLS}+\mathrm{X}$ & 2SLS & $2 S L S+X$ & OLS & $\mathrm{OLS}+\mathrm{X}$ & 2SLS & $2 \mathrm{SLS}+\mathrm{X}$ \\
\hline \multirow{3}{*}{$\begin{array}{l}\text { Number of } \\
\text { children }\end{array}$} & -0.069 & 0.202 & 0.278 & 0.370 & -0.215 & -0.297 & -0.388 & -0.369 \\
\hline & $(0.056)$ & $(0.098)$ & $(0.176)$ & $(0.175)$ & $(0.049)$ & $(0.102)$ & $(0.128)$ & $(0.128)$ \\
\hline & \multicolumn{4}{|c|}{ Control mean $=1.86, \mathrm{~N}=2335$} & \multicolumn{4}{|c|}{ Control mean $=2.07, \mathrm{~N}=2404$} \\
\hline \multirow{3}{*}{ Any children } & -0.032 & 0.023 & 0.017 & 0.031 & -0.071 & -0.060 & -0.081 & -0.075 \\
\hline & $(0.021)$ & $(0.036)$ & $(0.060)$ & $(0.060)$ & $(0.017)$ & $(0.031)$ & $(0.042)$ & $(0.042)$ \\
\hline & \multicolumn{4}{|c|}{ Control mean $=0.86, \mathrm{~N}=2232$} & \multicolumn{4}{|c|}{ Control mean $=0.9, \mathrm{~N}=2404$} \\
\hline \multirow{3}{*}{$\begin{array}{l}\text { Currently } \\
\text { married }\end{array}$} & 0.025 & 0.000 & -0.004 & -0.005 & 0.008 & 0.005 & 0.051 & 0.046 \\
\hline & $(0.022)$ & $(0.040)$ & $(0.063)$ & $(0.065)$ & $(0.019)$ & $(0.037)$ & $(0.048)$ & $(0.049)$ \\
\hline & \multicolumn{4}{|c|}{ Control mean $=0.86, \mathrm{~N}=2233$} & \multicolumn{4}{|c|}{ Control mean $=0.76, \mathrm{~N}=2401$} \\
\hline
\end{tabular}

Notes: see notes to Table 2. 